\title{
A Screening Pilot Study on the Relation between Body Mass Index, Heavy Metal and Mineral Levels in College Students
}

\author{
Asmaa Fathi Hamouda ${ }^{1,2,3}$, Ashraf Aly Moustafa Hassan²,3, Ibrahim Abdu \\ Khardali ${ }^{3}$, Ibraheem Mohammed Attafi ${ }^{3}$, Magbool Essa Oraiby ${ }^{3}$, Mohammad \\ Ahmad Attafi ${ }^{3}$, Madyha Hassan Mahmoud², Samia Farag Allah Salem², \\ Khaled Ali Yahya Sahli ${ }^{4}$, Fawaz Yahya Hamdi ${ }^{5}$, Hassan Abdu Ahmed Dohali ${ }^{6}$ \\ ${ }^{1}$ Department of Biochemistry, Faculty of Science, University of Alexandria, Alexandria, Egypt; \\ ${ }^{2}$ Department of Medical Laboratory Technology, Faculty of Applied Health Sciences, Jazan University, \\ Jazan, Kingdom of Saudi Arabia; \\ ${ }^{3}$ Center for Poison Control and Medical Forensic Chemistry, Ministry of Health, Jazan, Kingdom of \\ Saudi Arabia; \\ ${ }^{4}$ Clinics for Security Forces, Jazan, Kingdom of Saudi Arabia; \\ ${ }^{5}$ Samtah General Hospital, Jazan, Kingdom of Saudi Arabia; \\ ${ }^{6}$ Abu-arish General Hospital Jazan, Ministry of Health, Jazan, Kingdom of Saudi Arabia.
}

\begin{abstract}
*Corresponding author: Tel: 966500257869; E-mail: asmaakingdom1@yahoo.com
Citation: Hamouda AF, Moustafa Hassan AA, Khardali IA, et al. A Screening Pilot Study on the Relation Between Body Mass Index, Heavy Metal and Mineral Levels in College Students. Electronic J Biol. 15:3
\end{abstract}

Received: November 04, 2019; Accepted: November 18, 2019; Published: November 25, 2019

\section{Research Article}

\begin{abstract}
Obesity is a chronic metabolic disease identified by excessive fat deposition in the body with the highest risk of disordered lipid profile. Obesity and inappropriate lifestyles such as smoking and fake food not only influence blood lipids but also helps heavy metals and mineral be absorbed and adhered to the tissues with minimal disposal, that producing health problems with ages. A total of 49 female students (18-35 years old) included in this study to assess the relationship between body mass index, heavy metal, and minerals in university students. There is a strong correlation between $\mathrm{BMI}$ and potassium, where there is a positively weak relation between selected heavy metal and minerals and BMI. The increases in the presence of heavy metal and minerals in the present study not only depended in the BMI but also as a result of the rise in the effluent flow heavy metal from industrial units found in close nearness to rivers, oceans and seas have ended in an expansion in water bodies and seafood, fruits, vegetable crops and the food chain. That will need further investigation.
\end{abstract}

Keywords: Obesity; Body mass index; Heavy metal; Minerals

\section{Introduction}

Scientists reported that obesity is a medical disease in which excess body fat has accumulated in the body and produces a disadvantageous effect on health, leading to reduced life expectancy and increased health problems [1,2]. Obesity is measured by body mass index (BMI) and the waisthip ratio $[1,3]$. Obesity caused by a sequence of extreme food energy intake, loss of physical activity, and genetic susceptibility, genetic defect, endocrine disturbances, medications, or psychiatric illness $[2,4]$. The previous report established risk factors for obesity and related conditions is a lifestyle and environmental pollutants, including heavy metals such as cadmium and lead. There is more 20 metal such as heavy metals $(\mathrm{Pb}, \mathrm{Cd}$, mercury- $\mathrm{Hg}, \mathrm{As}, \mathrm{W})$, trace elements (calcium-Ca, $\mathrm{Fe}, \mathrm{Zn}, \mathrm{Cu}, \mathrm{Cr}, \mathrm{Mo}$, Se, $\mathrm{Mn}$ ) and $\mathrm{Na}, \mathrm{K}, \mathrm{Mg}$ that are named electrolytes. Fake food and canned food have heavy metals that may increase obesity, diabetes, and heart condition in the human body or severe weight loss [3-5]. Also, there are significant positive correlations between heavy metal, lipid profile, and obesity [5-9]. Thus, this study will perform in college students at Jazan University to provide primary data for the relation between BMI and heavy metal and minerals where Jazan in the Kingdom of Saudi Arabia is a coastal city.

\section{Subjects and Methods}

\subsection{Subjects}

A total of 49 female students, 18-35 years old, included in this study. The assessment takes place in the period 2017-2018. The protocol approved by 
the Declaration of Helsinki 2008 and approved by the University ethics committee. Written consent sign by each participant after a full description of the method of the investigation. All students have the liberty to depart any time during the study without any reason or sign of punishment. Subjects are classified into four groups according to BMI (underweight, normal, overweight, and obese). The subjects in menstruation or pregnant are excluded, and no smoking history of any subjects included in this study. An eating pattern to all subjects is canned food, fast food, fruit, vegetable, fish, seafood, meat, and manufacture food and juice. It also included dairy products and energy drinks. All subjects have no previous clinical problems such as diabetes, kidney, heart, thyroid, or other. Table 1 represented the subjects included criteria regarded as the correlation between $\mathrm{BMI}$ and lipid profile $(n=49)$.

\subsection{Methods}

\section{Anthropometrics}

The student's weights and heights were included on a single calibrated scale (SR Scales, SR Instruments). The formula calculated body mass index (BMI): weight in kilograms $(\mathrm{kg})$ divided by height in square meters $\left(m^{2}\right)$ [1,5-9].

\section{Laboratory investigations}

Blood was withdrawn after an overnight fast (>9 hours). Blood collected from healthy and obese students at Jazan University. Total cholesterol, triglyceride, high-density lipoprotein (HDL cholesterol), low-density lipoprotein (LDL cholesterol) measured in Abu-Arish general hospital Jazan in Saudi Arabia using Hitachi automatic analyzer c501 biochemistry. Assessment of heavy metal and mineral levels in serum samples dilutes and analyze on a PerkinElmer Elan DRC II inductively-coupled plasma mass spectrometer Poison Control and Medical Forensic Chemistry Center, Ministry of Health, Jazan in Saudi Arabia. Trace elements and heavy metals in soils and sediments are determined with atomic absorption spectrometry (AAS), inductively coupled plasma mass spectrometry (ICP-MS), and inductively coupled plasma optical emission spectrometer (ICP-OES) after acid digestion of the samples. With more convenience and multielement measurement capability, ICP-OES/ICP-MS has become an attractive instrument for simultaneously determined co-contaminants in environmental samples. The elemental profile was measured by inductively coupled plasma-mass spectrometry ICPMS (Agilent, $7500 \mathrm{cx}$ ) after separate serum samples and digested with nitric acid using a microwave digestion system (Milestone, Ethos 1) [9-11].

\section{Statistics}

Data were fed to the computer and examined using IBM SPSS software package version 20.0. (Armonk, NY: IBM Corp). The Kolmogorov- Smirnov, Shapiro, and D'agstino tests were used to verify the normality of distribution of variables, Judgments between groups for categorical variables were assessed using the Chi-square test. ANOVA was used to compare between more than two groups for normally distributed quantitative variables and followed by the Post Hoc test (Tukey) for pairwise comparison. Kruskal Wallis test was used to compare different groups for not normally distributed quantitative variables and followed by the Post Hoc test (Dunn's for multiple comparisons test) for pairwise comparison. Pearson coefficient was used to correlate between quantitative variables. The significance of the achieved results was judged at the $5 \%$ level.

\section{Result}

Table 1 represented the subjects included criteria of the correlation between BMI and lipid profile $(n=49)$. According to Evans (1996) who suggests for the absolute value of r: 0.00-0.19: "fragile," $0.20-0.39$ : "weak," 0.40-0.59: "moderate," 0.60-0.79: "strong," 0.80-1.0: "very strong," where there is appositively weakly relation between Cholesterol, and BMI. On the other support, there is a strong positive correlation between triglyceride, $\mathrm{LDL}$, and $\mathrm{BMI}$, and a negative relation between $\mathrm{HDL}$ and BMI. Table 2 represented the data and result of Correlation between BMI and heavy metal and minerals. According to Evans (1996) who suggests for the absolute value of $r$ : 0.00-0.19: "very weak", 0.20-0.39: "weak", 0.400.59: "moderate", 0.60-0.79: "strong", 0.80-1.0: "very strong", where there is appositively significant weakly relation between $(\mathrm{K})$, and $\mathrm{BMI}$, and appositively weakly relation $\mathrm{Na}, \mathrm{Mg}, \mathrm{Al}, \mathrm{Ca}, \mathrm{Ti}, \mathrm{Cr}, \mathrm{Mn}, \mathrm{Fe}, \mathrm{Co}, \mathrm{Ni}$, $\mathrm{Cu}, \mathrm{Zn}, \mathrm{Mo}, \mathrm{Cd}, \mathrm{Pb}$, and $\mathrm{BMI}$.

Table 3 shows the relation between BMI type and $\mathrm{Na}, \mathrm{Mg}, \mathrm{Al}, \mathrm{K}, \mathrm{Ca}, \mathrm{Ti}, \mathrm{Cr}, \mathrm{Mn}, \mathrm{Fe}, \mathrm{Co}, \mathrm{Ni}, \mathrm{Cu}, \mathrm{Zn}$, $\mathrm{Mo}, \mathrm{Cd}, \mathrm{Pb}$ in different studied group. In (Na) the data represented as Mean $\pm S D$ where there is anon significant difference between studied group (3.4 \pm $0.3,3.5 \pm 0.3,3.6 \pm 0.3,3.7 \pm 0.4$ ) in underweight, normal weight, overweight, obesity respectively and higher than as compared to normal range (3.08-3.31 $\mu \mathrm{g} / \mathrm{L})$. In (Mg) the data represented as Mean $\pm \mathrm{SD}$ where there is anon significant difference between studied group $(2.3 \pm 0.3,2.4 \pm 0.3,3.6 \pm 0.3,2.4$ \pm 0.3 ) in underweight, normal weight, overweight, obesity respectively. All group within the normal range except the overweight is higher than as compared to the normal range $(1.70-2.43 \mu \mathrm{g} / \mathrm{L})$. In $(\mathrm{Al})$ the data 
represented as Mean $\pm S D$ where there is anon significant difference between studied group (105.0 $\pm 277.8,24.9 \pm 54.0,204.6 \pm 4057,203.3 \pm 538.5)$ in underweight, normal weight, overweight, obesity respectively and higher than as compared to normal range $(0-9 \mu \mathrm{g} / \mathrm{L})$. In $(\mathrm{K})$ the data represented as Mean \pm SD where there is anon significant difference between studied group $(2.3 \pm 0.5,2.5 \pm 0.3,2.3$ $\pm 0.2,3.0 \pm 1.2$ ) in underweight, normal weight, overweight, obesity respectively and higher than as compared to normal range (1.368-2.033 $\mu \mathrm{g} / \mathrm{L})$. In $(\mathrm{Ca})$ the data represented as Mean \pm SD where there is anon significant difference between studied group $(10.9 \pm 1.4,11.2 \pm 1.1,11.7 \pm 1.3,11.6 \pm 1.1)$ in underweight, normal weight, overweight, obesity respectively and higher than as compared to normal range (8.7-10.2 $\mu \mathrm{g} / \mathrm{L})$. In $(\mathrm{Ti})$ the data represented as Mean $\pm S D$ where there is anon significant

Table 1. The subjects included criteria Correlation between $\mathrm{BMI}$ and lipid profile $(\mathrm{n}=49)$.

\begin{tabular}{|l|c|c|}
\hline \multirow{2}{*}{\multicolumn{1}{|c|}{ Lipid profile }} & \multicolumn{2}{c|}{ BMI $\left(\mathbf{k g} / \mathbf{m}^{2}\right)$} \\
\cline { 2 - 3 } & $\mathbf{r}$ & $\mathbf{p}$ \\
\hline Cholesterol $(\mathrm{mmol} / \mathrm{L})$ & 0.018 & 0.900 \\
\hline Triglyceride $(\mathrm{mmol} / \mathrm{L})$ & $0.383^{*}$ & $0.007^{*}$ \\
\hline $\mathrm{HDL}(\mathrm{mmol} / \mathrm{L})$ & $-0.567^{*}$ & $<0.001^{*}$ \\
\hline $\mathrm{LDL}(\mathrm{mmol} / \mathrm{L})$ & $0.330^{*}$ & $0.020^{*}$ \\
\hline
\end{tabular}

r: Pearson coefficient; *: Statistically significant at $p \leq 0.05$; Evans (1996) suggests for the absolute value of $r$ : 0.00-0.19: "fragile"; 0.20-0.39: "weak"; 0.40-0.59: "moderate"; 0.60-0.79: "strong"; 0.80-1.0: "very strong".

Table 2. Correlation between BMI and different metals parameters $(n=49)$.

\begin{tabular}{|l|c|c|}
\hline \multirow{2}{*}{\multicolumn{1}{|c|}{ Metals }} & \multicolumn{2}{c|}{ BMI $\left(\mathbf{k g} / \mathbf{m}^{2}\right)$} \\
\cline { 2 - 3 } $\mathrm{Na}\left(\times 10^{6}\right)(\mu \mathrm{g} / \mathrm{L})$ & $\mathrm{r}$ & $\mathrm{p}$ \\
\hline $\mathrm{Mg}\left(\times 10^{4}\right)(\mu \mathrm{g} / \mathrm{L})$ & 0.239 & 0.098 \\
\hline $\mathrm{Al}(\mu \mathrm{g} / \mathrm{L})$ & 0.162 & 0.265 \\
\hline $\mathrm{K}\left(\times 10^{5}\right)(\mu \mathrm{g} / \mathrm{L})$ & 0.197 & 0.176 \\
\hline $\mathrm{Ca}(\mu \mathrm{g} / \mathrm{L})$ & $0.305^{*}$ & $0.033^{*}$ \\
\hline $\mathrm{Ti}(\mu \mathrm{g} / \mathrm{L})$ & 0.176 & 0.228 \\
\hline $\mathrm{Cr}(\mu \mathrm{g} / \mathrm{L})$ & 0.197 & 0.176 \\
\hline $\mathrm{Mn}(\mu \mathrm{g} / \mathrm{L})$ & 0.220 & 0.129 \\
\hline $\mathrm{Fe}(\mu \mathrm{g} / \mathrm{L})$ & 0.245 & 0.089 \\
\hline $\mathrm{Co}(\mu \mathrm{g} / \mathrm{L})$ & 0.052 & 0.723 \\
\hline $\mathrm{Ni}(\mu \mathrm{g} / \mathrm{L})$ & 0.181 & 0.213 \\
\hline $\mathrm{Cu}(\mu \mathrm{g} / \mathrm{L})$ & 0.199 & 0.171 \\
\hline $\mathrm{Zn}(\mu \mathrm{g} / \mathrm{L})$ & 0.239 & 0.098 \\
\hline $\mathrm{Mo}(\mu \mathrm{g} / \mathrm{L})$ & 0.130 & 0.375 \\
\hline $\mathrm{Cd}(\mu \mathrm{g} / \mathrm{L})$ & 0.220 & 0.129 \\
\hline $\mathrm{Pb}(\mu \mathrm{g} / \mathrm{L})$ & 0.040 & 0.784 \\
\hline $\mathrm{F} \mathrm{PearsOn}$ & 0.010 & 0.948 \\
\hline
\end{tabular}

r: Pearson coefficient; *: Statistically significant at $p \leq 0.05$; Evans (1996) suggests for the absolute value of $r$ : 0.00-0.19: "very weak"; 0.20-0.39: "weak"; 0.40-0.59: "moderate"; 0.60-0.79: "strong"; 0.80-1.0: "very strong". difference between studied group (5.1 $\pm 0.7,5.2$ $\pm 0.7,5.2 \pm 0.6,5.5 \pm 1.1$ ) in underweight, normal weight, overweight, obesity respectively and higher than as compared to normal range $(0-1 \mu \mathrm{g} / \mathrm{L})$. $\ln (\mathrm{Cr})$ the data represented as Mean \pm SD where there is a non-significant difference between studied group $(401.0 \pm 57.1,765.2 \pm 989.1,415.6 \pm 84.8,8607.9 \pm$ 31117.6) in underweight, normal weight, overweight, obesity respectively as compared to each other and higher than as compared to normal range (0.1-2.1 $\mu \mathrm{g} / \mathrm{L}$ ) (Table 3). Also, In (Mn) the data represented as Mean \pm SD where there is a non-significant difference between studied group $(3.7 \pm 0.8,3.7 \pm 1.3,4.7 \pm 1$, $4.3 \pm 1.7$ in underweight, normal weight, overweight, obesity respectively as compared to each other and higher than as compared to normal range $(<2.5 \mu \mathrm{g} / \mathrm{L})$ (Table 3).

In $(\mathrm{Fe})$ the data represented as Mean $\pm \mathrm{SD}$ where there is a non-significant difference between studied group $(4.4 \pm 1.1,4.2 \pm 1.2,4.2 \pm 0.9,4.4 \pm 1.5)$ in underweight, normal weight, overweight, obesity respectively as compared to each other and less than as compared to normal range (15- $150 \mu \mathrm{g} / \mathrm{L})$. In (Co) the data represented as Mean \pm SD where there is a significant difference between studied group $(0.6 \pm 0.2,0.8 \pm 0.2,0.5 \pm 0.2,0.9 \pm 1.1)$ in underweight, normal weight, overweight, obesity respectively as compared to each other and within the reference range $(0.0-0.9 \mu \mathrm{g} / \mathrm{L})$. In $(\mathrm{Ni})$ the data represented as Mean \pm SD where there is a nonsignificant difference between studied group (55.1 $\pm 40.3,1541.7 \pm 4364.7,72.1 \pm 61.3,4009.9 \pm$ 14972.8) in underweight, normal weight, overweight, obesity respectively as compared to each other and higher than as compared to normal range $(<2 \mu \mathrm{g} / \mathrm{L})$ (Table 3$)$. In $(\mathrm{Cu})$ the data represented as Mean \pm SD where there is a significant difference between studied group $(2.2 \pm 0.3,6.4 \pm 11.9,2.6 \pm 0.3,7.6$ \pm 9.0 ) in underweight, normal weight, overweight, obesity respectively as compared to each other and all results within normal range $(7.2-16.6 \mu \mathrm{g} / \mathrm{L})$ (Table 3).

In $(\mathrm{Zn})$ the data represented as Mean \pm SD where there is a significant difference between studied group $(10.3 \pm 3.4,9.8 \pm 1.9,9.3 \pm 2.8,10.5 \pm 4.5)$ in underweight, normal weight, overweight, obesity respectively as compared to each other and all results within normal range $(6.6-11.0 \mu \mathrm{g} / \mathrm{L})$ (Table 3 ). In (Mo) the data represented as Mean \pm SD where there is a significant difference between studied group $(2.1 \pm 5.6,48.0 \pm 126.9,4.0 \pm 8.0,1017.1 \pm$ 3839.9) in underweight, normal weight, overweight, 
Table 3. Relation between BMI type and different parameters $(n=49)$.

\begin{tabular}{|c|c|c|c|c|c|c|}
\hline \multirow[b]{2}{*}{ Individual parameters } & \multicolumn{4}{|c|}{ BMI type $\left(\mathrm{kg} / \mathrm{m}^{2}\right)$} & \multirow{2}{*}{$\begin{array}{r}\text { Test of } \\
\text { sig. }\end{array}$} & \\
\hline & $\begin{array}{c}\text { Underweight } \\
(\mathrm{n}=7)\end{array}$ & $\underset{(n=9)}{\text { Normal weight }}$ & $\underset{(n=4)}{\text { Overweight }}$ & $\begin{array}{l}\text { Obesity } \\
(n=29)\end{array}$ & & \\
\hline \multicolumn{7}{|l|}{$\mathrm{Na}(\mu \mathrm{g} / \mathrm{L}) \times 1^{0} 6$} \\
\hline Median (Min-Max.) & $3.4(3.1-4.1)$ & $3.6(3.0-3.9)$ & $3.8(3.3-3.8)$ & $3.7(3.0-4.4)$ & \multirow{2}{*}{$F=1.009$} & \multirow{2}{*}{0.397} \\
\hline Mean \pm SD. & $3.4^{a} \pm 0.3$ & $3.5^{\mathrm{a}} \pm 0.3$ & $3.6^{a} \pm 0.3$ & $3.7^{a} \pm 0.4$ & & \\
\hline \multicolumn{7}{|l|}{$M g(\mu g / L) \times 10^{4}$} \\
\hline Median (Min-Max.) & $2.3(2.0-2.7)$ & $2.4(2.0-2.8)$ & $2.5(2.0-3.0)$ & $2.4(1.9-3.0)$ & \multirow{2}{*}{$F=0.803$} & \multirow{2}{*}{0.499} \\
\hline Mean \pm SD & $2.3^{a} \pm 0.3$ & $2.4^{\mathrm{a}} \pm 0.3$ & $2.5^{\mathrm{a}} \pm 0.4$ & $2.4^{a} \pm 0.3$ & & \\
\hline \multicolumn{7}{|l|}{$\mathrm{Al}(\mu \mathrm{g} / \mathrm{L})$} \\
\hline Median (Min-Max.) & $0.0(0.0-735.0)$ & $1.3(0.0-166.2)$ & $2.6(0.0-813.2)$ & $3.9(0.0-2316.0)$ & \multirow{2}{*}{$\mathrm{H}=3.027$} & \multirow{2}{*}{0.387} \\
\hline Mean \pm SD & $105.0^{\mathrm{a}} \pm 277.8$ & $24.9^{\mathrm{a}} \pm 54.0$ & $204.6^{a} \pm 405.7$ & $203.3^{a} \pm 538.5$ & & \\
\hline \multicolumn{7}{|l|}{$\mathrm{K}(\mu \mathrm{g} / \mathrm{L}) \times 105$} \\
\hline Median (Min-Max.) & $2.1(1.8-3.1)$ & $2.3(2.0-3.1)$ & $2.4(2.0-2.5)$ & $2.6(2.0-7.1)$ & \multirow{2}{*}{$H=5.759$} & \multirow{2}{*}{0.124} \\
\hline Mean \pm SD & $2.3^{a} \pm 0.5$ & $2.5^{\mathrm{a}} \pm 0.3$ & $2.3^{\mathrm{a}} \pm 0.2$ & $3.0^{\mathrm{a}} \pm 1.2$ & & \\
\hline \multicolumn{7}{|l|}{$\mathrm{Ca}(\mu \mathrm{g} / \mathrm{L}) \times 10^{4}$} \\
\hline Median (Min-Max.) & $10.4(9 .-13.8)$ & $10.8(9.6-12.8)$ & $12(9.8-12.7)$ & $11.5(9.8-13.4)$ & \multirow{2}{*}{$F=0.646$} & \multirow{2}{*}{0.589} \\
\hline Mean \pm SD & $10.9^{\mathrm{am}} \pm 1.4$ & $11.2^{\mathrm{a}} \pm 1.1$ & $11.7^{\mathrm{a}} \pm 1.3$ & $11.6^{\mathrm{a}} \pm 1.1$ & & \\
\hline \multicolumn{7}{|l|}{$\mathrm{Ti}(\mu \mathrm{g} / \mathrm{L}) \times 10^{2}$} \\
\hline Median (Min-Max.) & $5.1(4.4-6.4)$ & $5.4(3.8=5.9)$ & $5.2(4.6-5.8)$ & $5.5(3.3-8.6)$ & \multirow{2}{*}{$F=0.491$} & 0601 \\
\hline Mean \pm SD. & $5.1^{\mathrm{a}} \pm 0.7$ & $5.2^{\mathrm{a}} \pm 0.7$ & $5.2^{\mathrm{a}} \pm 0.6$ & $5.5^{\mathrm{a}} \pm 1.1$ & & 0.691 \\
\hline $\mathrm{Cr}(\mu \mathrm{g} / \mathrm{L})$ & & & & & & \\
\hline Median (Min-Max.) & $399.7(311-499.6)$ & $462(296.6-3397)$ & $407.2(321.8-526.1)$ & $401.3(308.5-141600)$ & & \\
\hline Mean \pm SD & $401.0^{\mathrm{a}} \pm 57.1$ & $765.2^{\mathrm{a}} \pm 989.1$ & $415.6^{\mathrm{a}} \pm 84.8$ & $8607.9^{a} \pm 31117.6$ & $\mathrm{H}=1.85 /$ & 0.603 \\
\hline $\mathrm{Mn}(\mu \mathrm{g} / \mathrm{L})$ & & & & & & \\
\hline $\begin{array}{l}\text { Median (Min - } \\
\text { Max.) }\end{array}$ & $3.7(2.6-4.9)$ & $3.6(1.8-6.4)$ & $4.7(3.6-5.7)$ & $3.9(2.5-10.3)$ & $\mathrm{H}=3.203$ & 0.361 \\
\hline Mean \pm SD & $3.7^{a} \pm 0.8$ & $3.7^{\mathrm{a}} \pm 1.3$ & $4.7^{a} \pm 1$ & $4.3^{a} \pm 1.7$ & & \\
\hline $\mathrm{Fe}(\mu \mathrm{g} / \mathrm{L}) \times 103$ & & & & & & \\
\hline Median (Min- Max.) & $3.9(3.3-6.1)$ & $4.7(2.7-5.9)$ & $4.3(2.9-5.1)$ & $4.1(3-9.7)$ & $F=0,63$ & 0979 \\
\hline Mean \pm SD. & $4.4^{\mathrm{a}} \pm 1.1$ & $4.2^{\mathrm{a}} \pm 1.2$ & $4.2^{\mathrm{a}} \pm 0.9$ & $4.4^{\mathrm{a}} \pm 1.5$ & $r=0.063$ & 0.919 \\
\hline Co $(\mu \mathrm{g} / \mathrm{L})$ & & & & & & \\
\hline Median (Min- Max.) & $0.7(0.3-0.9)$ & $0.8(0.5-1.2)$ & $0.5(0.2-.6)$ & $0.7(0.2-5.8)$ & & \\
\hline Mean \pm SD & $0.6^{\mathrm{abc}} \pm 0.2$ & $0.8^{b} \pm 0.2$ & $0.5^{\complement} \pm 0.2$ & $0.9^{\mathrm{a}} \pm 1.1$ & .548 & 0.023 \\
\hline $\mathrm{Ni}(\mu \mathrm{g} / \mathrm{L})$ & & & & & & \\
\hline Median (Min- Max.) & $39.7(33.5-145.8)$ & $52.1(42.9-13180)$ & $45.7(33.4-163.6)$ & $47(29.9-68170)$ & 662 & 0198 \\
\hline Mean \pm SD. & $55.1^{\mathrm{a}} \pm 40.3$ & $1541.7^{\mathrm{a}} \pm 4364.7$ & $72.1^{\mathrm{a}} \pm 61.3$ & $4009.9^{a} \pm 14972.8$ & $H=4.662$ & 0.198 \\
\hline $\mathrm{Cu}(\mu \mathrm{g} / \mathrm{L}) \times 10^{2}$ & & & & & & \\
\hline Median (Min- Max.) & $2.2(2-2.8)$ & $2.4(1.9-38.2)$ & $2.7(2.2-2.9)$ & $2.9(2-33.3)$ & & ?ח? \\
\hline Mean \pm SD & $2.2^{b} \pm 0.3$ & $6.4^{\mathrm{b}} \pm 11.9$ & $2.6^{\mathrm{ab}} \pm 0.3$ & $7.6^{a} \pm 9.0$ & $H=14.480$ & 0.002 \\
\hline $\mathrm{Zn}(\mu \mathrm{g} / \mathrm{L}) \times 10^{2}$ & & & & & & \\
\hline Median (Min- Max.) & $8.7(7.2-16.4)$ & $9.7(7.7-13.8)$ & $9.1(6.2-12.8)$ & $9.4(5.7-30.9)$ & $\mathrm{H}=0108$ & 0991 \\
\hline Mean \pm SD & $10.3^{a} \pm 3.4$ & $9.8^{\mathrm{a}} \pm 1.9$ & $9.3^{a} \pm 2.8$ & $10.5^{\mathrm{a}} \pm 4.5$ & $\mathrm{H}=0.108$ & 0.991 \\
\hline Mo $(\mu \mathrm{g} / \mathrm{L})$ & & & & & & \\
\hline Median (Min- Max.) & $0(0-14.9)$ & $0(0-385.9)$ & $0(0-16)$ & $0(0-17280)$ & $\mathrm{H}=1706$ & 0616 \\
\hline Mean \pm SD. & $2.1^{\mathrm{a}} \pm 5.6$ & $48.0^{a} \pm 126.9$ & $4.0^{\mathrm{a}} \pm 8.0$ & $1017.1^{\mathrm{a}} \pm 3839.9$ & $\mathrm{H}=1.796$ & 0.616 \\
\hline $\mathrm{Cd}(\mu \mathrm{g} / \mathrm{L})$ & & & & & & \\
\hline Median (Min- Max.) & $30(15.6-39)$ & $32.6(17.1-40.9)$ & $23.9(17.5-31.9)$ & $27.3(9.4-45.6)$ & 651 & 0587 \\
\hline Mean \pm SD & $29.2^{\mathrm{a}} \pm 8.0$ & $31.1^{\mathrm{a}} \pm 8.9$ & $24.3^{\mathrm{a}} \pm 6.0$ & $28.2^{\mathrm{a}} \pm 8.5$ & $r=0.651$ & 0.581 \\
\hline $\mathrm{Pb}(\mu \mathrm{g} / \mathrm{L})$ & & & & & & \\
\hline Median (Min-Max.) & $0.6(0.1-1)$ & $0.7(0-1)$ & $0.4(0-1)$ & $0.4(0-1.8)$ & & \\
\hline Mean \pm SD & $0.6^{\mathrm{a}} \pm 0.3$ & $0.5^{\mathrm{a}} \pm 0.4$ & $0.4^{\mathrm{a}} \pm 0.4$ & $0.5^{\mathrm{a}} \pm 0.5$ & & \\
\hline
\end{tabular}

Underweight: <18.5; Normal weight: 18.5-24.9;Overweight: 25-29.9; Obesity: BMl of 30 or greater; $\chi^{2}$ : Chi square test; $\mathrm{H}$ : $\mathrm{H}$ for Kruskal Wallis test; Pairwise comparison bet. Each 2 categories was done using Post Hoc Test (Dunn's for multiple comparisons test); F: F for ANOVA test; Pairwise comparison bet. each 2 categories was done using Post Hoc Test (Tukey); $p$ : $p$ value for comparing between the four categories; Means with Common letters are not significant. 
Table 4. The percent of the normal cases in different parameters $(n=49)$.

\begin{tabular}{|c|c|c|c|c|c|c|}
\hline \multirow[b]{2}{*}{$\begin{array}{l}\text { Individual parameter } \\
\text { (reference range) }\end{array}$} & \multicolumn{4}{|c|}{ BMI type $\left(\mathrm{kg} / \mathrm{m}^{2}\right)$} & \multirow[b]{2}{*}{$\begin{array}{l}\text { Test of } \\
\text { sig. }\end{array}$} & \multirow[b]{2}{*}{${ }^{\mathrm{MC}} \mathbf{p}$} \\
\hline & $\begin{array}{l}\text { Underweight } \\
\qquad(n=7)\end{array}$ & $\begin{array}{c}\text { Normal } \\
\text { weight } \\
(n=9)\end{array}$ & $\begin{array}{l}\text { Overweight } \\
\qquad(n=4)\end{array}$ & $\begin{array}{l}\text { Obesity } \\
(n=29)\end{array}$ & & \\
\hline $\mathrm{Na}(\mu \mathrm{g} / \mathrm{L}) \times 10^{6}(3.08-3.31)$ & $2(28.6 \%)$ & $1(11.1 \%)$ & $1(25.0 \%)$ & $6(20.7 \%)$ & $x^{2}=1.195$ & 0.850 \\
\hline $\mathrm{Mg}(\mu \mathrm{g} / \mathrm{L}) \times 10^{4}(1.70-2.43)$ & $5(71.4 \%)$ & $6(66.7 \%)$ & $2(50.0 \%)$ & $15(51.7 \%)$ & $x^{2}=1.427$ & 0.715 \\
\hline $\mathrm{Al}(\mu \mathrm{g} / \mathrm{L})(0-9)$ & $6(85.7 \%)$ & $5(55.6 \%)$ & $3(75.0 \%)$ & $18(62.1 \%)$ & $x^{2}=1.885$ & 0.678 \\
\hline $\mathrm{K}(\mu \mathrm{g} / \mathrm{L}) \times 10^{5}(1.368-2.033)$ & $3(42.9 \%)$ & $1(11.1 \%)$ & $1(25.0 \%)$ & $13.4 \%)$ & $x^{2}=8.068^{*}$ & 0.020 \\
\hline $\mathrm{Ca}(\mu \mathrm{g} / \mathrm{L}) \times 10^{4}(8.7-10.2)$ & $3(42.9 \%)$ & $1(11.1 \%)$ & $1(25.0 \%)$ & $4(13.8 \%)$ & $x^{2}=3.632$ & 0.253 \\
\hline $\mathrm{Ti}(\mu \mathrm{g} / \mathrm{L}) \times 10^{2}(0-1)$ & $0(0.0 \%)$ & $0(0.0 \%)$ & $0(0.0 \%)$ & $0(0.0 \%)$ & - & - \\
\hline $\mathrm{Cr}(\mu \mathrm{g} / \mathrm{L})(0.1-2.1)$ & $0(0.0 \%)$ & $0(0.0 \%)$ & $0(0.0 \%)$ & $0(0.0 \%)$ & - & - \\
\hline $\mathrm{Mn}(\mu \mathrm{g} / \mathrm{L})(<2.5)$ & $0(0.0 \%)$ & $1(11.1 \%)$ & $0(0.0 \%)$ & $0(0.0 \%)$ & $x^{2}=4.608$ & 0.407 \\
\hline $\mathrm{Fe}(\mu \mathrm{g} / \mathrm{L}) \times 10^{3}(15-150)$ & $0(0.0 \%)$ & $0(0.0 \%)$ & $0(0.0 \%)$ & $0(0.0 \%)$ & - & - \\
\hline Co $(\mu \mathrm{g} / \mathrm{L})(0.0-0.9)$ & $6(85.7 \%)$ & $7(77.8 \%)$ & $4(100.0 \%)$ & $26(89.7 \%)$ & - & - \\
\hline $\mathrm{Ni}(\mu \mathrm{g} / \mathrm{L})(<2)$ & $0(0.0 \%)$ & $0(0.0 \%)$ & $0(0.0 \%)$ & $0(0.0 \%)$ & - & - \\
\hline $\mathrm{Cu}(\mu \mathrm{g} / \mathrm{L}) \times 10^{2}(7.2-16.6)$ & $0(0.0 \%)$ & $0(0.0 \%)$ & $0(0.0 \%)$ & $5(17.2 \%)$ & $x^{2}=2.204$ & 0.544 \\
\hline $\mathrm{Zn}(\mu \mathrm{g} / \mathrm{L}) \times 10^{2}(6.6-11.0)$ & $5(71.4 \%)$ & $7(77.8 \%)$ & $2(50.0 \%)$ & $17(58.6 \%)$ & $x^{2}=1.646$ & 0.690 \\
\hline Mo $(\mu \mathrm{g} / \mathrm{L})(0.3-2.0)$ & $0(0.0 \%)$ & $0(0.0 \%)$ & $0(0.0 \%)$ & $00.0 \%)$ & - & - \\
\hline $\mathrm{Cd}(\mu \mathrm{g} / \mathrm{L})(0-4.9)$ & $0(0.0 \%)$ & $0(0.0 \%)$ & $0(0.0 \%)$ & $0(0.0 \%)$ & - & - \\
\hline $\mathrm{Pb}(\mu \mathrm{g} / \mathrm{L})(0-190)$ & $7(100.0 \%)$ & $9(100.0 \%)$ & $4(100.0 \%)$ & $29(100.0 \%)$ & - & - \\
\hline
\end{tabular}

obesity respectively as compared to each other and higher than as compared to normal range ((0.3-2.0 $\mu \mathrm{g} / \mathrm{L})$ (Table 3).

In (Cd) the data represented as Mean \pm SD where there is a non-significant difference between studied group $(29.2 \pm 8.0,31.1 \pm 8.9,24.3 \pm 6.0,28.2 \pm 8.5)$ in underweight, normal weight, overweight, obesity respectively as compared to each other and higher than as compared to normal range (0-4.9 $\mu \mathrm{g} / \mathrm{L})$ (Table $3)$. In $(\mathrm{Pb})$ the data represented as Mean \pm SD where there is a non-significant difference between studied group $(0.6 \pm 0.3,0.5 \pm 0.4,0.4 \pm 0.4,0.5 \pm 0.5)$ in underweight, normal weight, overweight, obesity respectively as compared to each other and higher than as compared to normal range $(0-\mu \mathrm{g} / \mathrm{L})$ (Table 3$)$. Table 4 represents the percent of the normal cases of different studied parameters in the different studied groups, where Fisher's exact test is used.

\section{Discussion}

The predominance of obesity has more than doubled between children and tripled with adolescents in the last 30 years. There several causes of obesity, including genetic predisposition, food and caloric input, and lifestyle. Furthermore, the increased use of organic and inorganic chemicals for an extended range of applications in the last century has been paralleled by raises in the body weight, environmental pollutants, many of the endocrine disruptors, and imbalance in lipid and biological profile. In animal models, in vitro, and humans, many of these chemicals have been associated with lipid accumulation and progressive cardiometabolic dysfunctions. Moreover, a group of observations is suggesting that a relationship between heavy metal and mediated obesity in human populations [11-13]. The present work showed that there is an appositively significant weakly relation between $\mathrm{K}$ and $\mathrm{BMI}$. And appositively weakly association between $\mathrm{Na}, \mathrm{Mg}, \mathrm{Al}$, $\mathrm{Ca}, \mathrm{Ti}, \mathrm{Cr}, \mathrm{Mn}, \mathrm{Fe}, \mathrm{Co}, \mathrm{Ni}, \mathrm{Cu}, \mathrm{Zn}, \mathrm{Mo}, \mathrm{Cd}, \mathrm{Pb}$, and $\mathrm{BMI}$. On the other guidance, there is a strong positive correlation between triglyceride, LDL, and BMI and a negative relation between $\mathrm{HDL}$ and BMI. Also, there is no significant difference between studied heavy metal in the most different studied group as compared to each other. The present studies metals showed results more than normal range except $\mathrm{Mg}$, $\mathrm{Co}, \mathrm{Cu}, \mathrm{Zn}$ are within the normal range, but Fe results are less than normal range in all studied groups. These results may be due to the effect of lifestyle and environmental pollution and toxicity, including water, air, and food [6-9].

Some lighter metals and metalloids are poisonous and, thus, are named heavy metals though some heavy metals, such as gold, are not toxic. Heavy metals incorporate some metalloids, transition metals, essential metals, lanthanides, and actinides. Although some metals meet specific criteria and not 
others, most would recognize the elements mercury, bismuth, and lead are toxic metals with adequately high density. Models of heavy metals involve lead, mercury, cadmium, seldom chromium. Few ordinarily, metals containing iron, copper, zinc, aluminum, beryllium, cobalt, manganese, and arsenic may be supposed heavy metals [5-7].

The metallic elements, including mercury, arsenic, and lead that are capable of inducing toxicity even at lower levels of exposure, are supposed systemic toxicants. They involved the top point on the list of hazardous materials. Heavy metal toxicity has verified to be a significant warning, and there are different health risks associated with it. The toxic effects of these metals, even they do not have any physiological purpose, still existing in some of the other forms dangerous for the human body and its proper functioning. They sometimes serve as a pseudo-element of the body, while at specific times, they may even conflict with metabolic rules. Some metals, such as aluminum, can be eliminated through elimination actions, while some metals get stored in the body and food chain, displaying a chronic nature. Numerous public health models have been tried to control, prevent, and treat metal toxicity occurring at several levels, such as occupational exposure, accidents, and environmental circumstances. Metal toxicity depends upon the consumed dose, the path of exposure, and duration of exposure, i.e., acute or chronic way [6-8]. The cytotoxic actions can lead to multiple disturbances and can also result in extreme damage due to oxidative stress induced by free radical generation. Cytotoxic mechanisms of heavy metalinduced toxicity have been examined widely and recorded by various researchers. The heavy metal has the potential to generate highly reactive chemical substances such as free radicals, that cause oxidation of sulfhydryl groups of proteins, depletion of protein, DNA damage, lipid peroxidation, and various other effects. The main factors causing the high increase to toxicity for different metals include the formation of reactive oxygen (ROS) and nitrogen (RNS) species that disturb cell redox systems. A rise in ROS/RNS generation or decrease in ROS-scavenging action that appears as a result of exogenous stimuli has been observed to alter cellular functions. This alteration through direct changes of biomolecules and by significant stimulation/suppression of specific signaling pathways influencing growth factor receptors [14-16].

Lead $(\mathrm{Pb})$ is one of the sufficient natural elements on earth. It has widespread industrial use, including digging, smelting, refining, battery production, fertilizers and pesticide used for agriculture goals, and in increasing the octane rating of gasoline in vehicular traffic rules. As a result of accelerated industrialization, the rise in the effluent flow from industrial units found in close nearness to rivers, oceans, and seas have ended in an expansion in lead amount in water bodies and seafood, fruits, and vegetable crops [16-18], this may agree with the present work. Lead extensive contamination of the environment has caused severe health problems in many parts of the world. The acute display can make the loss of appetite, headache, hypertension, abdominal pain, renal dysfunction, fatigue, insomnia, arthritis, hallucinations, and vertigo. The chronic exposure can appear in intellectual incapacity, birth deformities, psychosis, autism, allergies, dyslexia, weight loss, hyperactivity, paralysis, muscular weakness, brain damage, kidney damage, and even death [19-21]. Lead in the body is spread to the brain, liver, kidney, and bones. It is stored in the teeth and bones, where it expands over time. Human lead exposure is evaluated through the estimation of lead in blood. Lead exposure has been connected to some health consequences in adults. High blood lead levels greater than $15 \mu \mathrm{g} / \mathrm{dL}$ are linked with cardiovascular effects, nerve dysfunctions, reduced kidney function, and fertility difficulties, including delayed understanding and adverse impacts on sperm and semen, such as lower sperm counts and motility. Blood lead levels below $10 \mu \mathrm{g} / \mathrm{dL}$ are associated with reduced kidney function and increases in blood pressure, hypertension, and incidence of essential nerves shaking. There is also a sign showing that adults who have low levels of exposure to lead less than five $\mu \mathrm{g} / \mathrm{dL}$ may have decreased kidney function [21-23].

There are many kinds of research recommending that animals exposed to lead exposure led to obesity. Other demonstrated reported that perinatal lead exposure at blood lead level (BLL) between $4.1 \mu \mathrm{g} / \mathrm{dL}$ and $32 \mu \mathrm{g} / \mathrm{dL}$ was joined with increased food intake, body weight, and total body fat in male mice. Also, previous studies reported that rises in body weight were remarked in year-old gestational lead exposure to male mice. Another investigation said that BLL has a sex-specific association with obesity $[24,25]$. While a study investigated the association between prenatal exposure to lead and the risk of low birth weight the correlation was significant among female infants, but not in male infants. Some studies also investigated the association between BLL and sex hormones, though they are limited and uncertain $[26,27]$. Several candidates may explain the lead-induced obesity, that not agree with the present study. First, lead has been linked to an altered hypothalamic-pituitaryadrenal axis, which can induce obesity. Even low 
BLL can alter children's adrenocortical responses to acute stress. Previous reports showed that lead exposure was not connected with initial salivary cortisol levels. Still, after an acute stressor, high BLL was significantly linked with the elevation of cortisol responses, indicating a lead-induced hypothalamicpituitary-adrenal axis dysregulation. Lead exposure itself could also influence a stress-like reaction and elevate ACTH and corticosterone concentrations. There is a clear indication that oxidative stress and fat metabolism abnormality could create a lousy circle and lead to obesity. Studies showed that leadinduced the production of reactive oxygen species while hindering their scavenging and neutralization by antioxidant defense mechanisms so it is understandable to understand that lead exposure may induce obesity slightly through oxidative stress $[28,29]$. Other investigations reported that BLLs are linked with lower body mass index and obesity in children, adolescents, and adults [30-32]. Other investigators found that low blood levels of lead associated with an increase in the prevalence of obesity and increase a risk factor for kidney damage [31-33].

Aluminum is one of the common elements spread on earth and has been recognized as a potentially toxic substance harmful to humans and animals. Human body damages due to the susceptibility to extremely concentrated aluminum. The toxicity includes aluminosis of the lung, neurotoxicity containing aluminum encephalopathy, myelotoxicity, and anemia. Aluminum can be absorbed from water, food additives, foods, aluminum cooking tools, and containers, about 30-50 mg a day. Under standard physiologic circumstances, the typical daily dietary intake of aluminum (5-10 mg) is eliminated [3436]. Excretion is performed by the avid filtration of aluminum from the blood by the glomeruli of the kidney. Patients in renal failure (RF) lose the capacity to remove aluminum and are applicants for aluminum toxicity. If renal filtration does not eliminate aluminum, it accumulates in the blood where it connects to proteins such as albumin and is quickly distributed through the body. Aluminum overload leads to a buildup of aluminum at the brain and bone. Brain deposition has been associated with a condition of dialysis dementia. In bone, aluminum replaces calcium at the mineralization front, disturbing healthy osteoid development. A recent report found that blood aluminum was significantly higher in college students due to improper dietary habits and imbalanced nutritional intake that elevation also associated with the degree of obesity in college students and lipid profiles [36,37].
The global population may be exposed to cadmium daily within the food, cigarette smoke, drinking water, and air. Cadmium is included in the food chain through agricultural soils. The raised levels of cadmium in food are detected in leafy vegetables, such as lettuce and spinach, potatoes, grains, peanuts, seafood, and organ meats such as liver and kidney. Cadmium levels are supposed to be low in drinking water and ambient air without in the vicinity of cadmiumemitting industries. Previous results suggest that the immunological consequences of lead and cadmium toxicity may be linked with increased susceptibility to chronic infectious diseases. Multiple studies have confirmed a relationship between environmental susceptibility to hazardous chemicals, including toxic metals and obesity, diabetes, and elaborate metabolic syndrome [38-40]. At the same time, the precious data on the impact of cadmium exposure on obesity and diabetes are contradictory that agree with the previous report, where unique biological mechanisms linking $\mathrm{Cd}$ display with obesity are still to be adequately studied. Other findings presented evidence for the influence of cadmium on blood pressure and the currency of hypertension in American adults $[41,42]$. That agrees with the present study where there is an elevation of blood cadmium in all studied groups as compared to the reference range; this may be contamination of food and water. In the present work, there is an elevation in all studied groups at $\mathrm{Mn}$ level as compared to normal range and not depended on BMI; this may be contamination of food and water as a result of environmental and global pollution. Manganese catalyzes the breakdown of fats and cholesterol. It is required for the metabolism of vitamin B1, C, and E, and for activation of different enzymes which are necessary for proper metabolism and utilization of foods. It was observed that serum levels of Mn were significantly lower in diabetic obese women than those with healthy. Also, serum $\mathrm{Mn}$ levels were negatively connected with serum insulin levels in fat diabetic women. It has been stated that people with diabetes may often have a critical $\mathrm{Mn}$ deficiency. Appropriate $\mathrm{Mn}$ levels are needed for the development of regular insulin synthesis and secretion. The general population is shown to manganese through the eating of food and water, inhaling of air, and dermal touch with air, water, soil, contaminated seafood consumer products that include manganese. The breath of air contaminated with particulate matter, including manganese, is the main root of excess manganese exposure for the global population in the United States. Inhaled manganese is often carried directly to the brain before the liver metabolizes it. The symptoms of manganese toxicity may develop gradually over months and years. 
Manganese toxicity can produce in a permanent neurological dysfunction recognized as manganism with symptoms that include tremors, trouble walking, and facial muscle spasms. These symptoms are often led by other secondary symptoms, including irritability, aggressiveness, and hallucinations. Some studies suggest that manganese inhalation can also result in adverse cognitive effects, including trouble with concentration and memory problems $[8,14]$.

Chromium ( $\mathrm{Cr}$ ) was first discovered to be an essential trace element. Chromium (Cr), was found in high concentrations and led to toxicity through rout of toxicity from the air, water, soil, that agree with the present work. The global population is exhibited to chromium by eating food or food supplements, drinking water, and inhaling air that contain chromium. Chromium waste residue, including potentially hazardous levels of $\mathrm{Cr}(\mathrm{VI})$ compounds, was applied as fill material at more than 160 domestic, industrial, and recreational places. Persons residing or working in the region of the areas may have been exposed through inhalation, ingestion, or skin contact with contaminated soils, dust, water, food like fruit or vegetable, and seafood. Chromium deficiency was documented in patients in association with total parenteral nutrition. Appropriate $\mathrm{Cr}$ supplementation for total parenteral nutrition patients should be carefully assessed. Total parenteral nutrition (PN) is the feeding of a person intravenously, bypassing the normal process of eating and digestion. The person takes nutritional formulae that contain nutrients such as glucose, salts, amino acids, lipids, and joined vitamins and dietary minerals [43-45]. The recent report found that Chromium ( $\mathrm{Cr}$ ), was found in high concentrations in the patients on shortterm total parenteral nutrition high concentrations of this element during parenteral nutrition over an expansive period $[44,45]$. Recent results showed no association between serum $\mathrm{Cr}$ levels and obesity, that agree with the present investigation. It has been demonstrated that chromium supplementation reduces body weight, regulates hunger, and also reduces body fat. Such variation may be due to race, lifestyle, geographical control, and even analytical methods. Dietary deficiency of $\mathrm{Cr}$ is considered to be positively associated with the risk of diabetes and its complications [46,47].

Nickel is the fourth most utilized metal in the world, and its consumption is projected to grow used for various industrial products and medical appliances (Roskill analysis). As a natural element of the earth's coating, small amounts are found in water, soil, and natural foods. The primary dietary source of Nickel is plant food. Plant tissues include more Nickel than an animal. Nickel is an ideal sensitizing agent, and it is useful for the highest incidence of skin sensitization and systemic signs. Systemic Nickel allergy syndrome is clinically described by cutaneous and systemic symptoms (such as a headache, asthenia, itching, and gastrointestinal complications related to histopathologic changes in gastrointestinal mucosa). It has been published that the prevalence of Nickel allergy in the general population is $8-15 \%$ for females and $1-3 \%$ for males. The previous investigation reported a high prevalence of Nickel allergy in overweight subjects, particularly women with metabolic syndrome in the perimenopause $[48,49]$.

Moreover, they notice that a low Nickel diet was effective in reducing BMI in their investigation, but they reported that further research is wholly needed to confirm this preliminary conclusion $[48,49]$. They indicate that, avoiding foods that include nickel significantly diminish body fat and body-mass index in overweight women allergic to the metal, especially those in early menopause. The study reported that an unusually high prevalence of nickel allergy in women and men who were overweight or obese compared with the healthy population. Nickel, a trace element present in water, soil, and food, is the cause of metal allergies. Foods that contain high levels of nickel incorporate whole grains, cocoa, legumes, and a group of vegetables. The allergic subjects were directed to a balanced, normal-calorie diet that eliminated or modified foods containing higher concentrations of nickel. Nickel allergies and decreasing estrogen levels have been associated with previous studies to the risen production of IL-17, an inflammatory protein connected with obesity. High concentrations of nickel could also affect gut bacteria that trigger an inflammation rule in obese people $[48,49]$. In the present study, we notice that there are, and elevation, the nickel concentration in all studied groups as compared to the normal range but have a weak correlation with BMI.

Iron in the form of hemoproteins and iron-sulfur is the sufficient transition metal in the human body, in present work $\mathrm{Fe}$ showed low level in all studied groups ad compared to normal range may be due to lifestyle. Ferritin is a blood cell protein that includes iron. Low ferritin amounts present an absolute sign of iron deficiency. Obesity induces subclinical inflammation that results in the secretion of numerous bioactive peptides that are affected in the metabolic regulation of iron homeostasis. Recent data shows that individuals with high BMI had high levels of serum ferritin. High level of ferritin despite low levels of iron with raised levels of $\mathrm{C}$ - reactive 
protein $[11,50]$ that agree with the present work, there is a decrease of $\mathrm{Fe}$ concentrations in all body mass index including underweight, normal, overweight, and obese females. The current results of $\mathrm{Ti}, \mathrm{Na}, \mathrm{K}$, Ca showed a higher level in all present studies as compared to the normal range, it may be due to the food composition and lifestyle. Titanium dioxide $\left(\mathrm{TiO}_{2}\right)$ is a food additive detected in a significant section of processed food products that consumed consume, including dairy, cereals, sauces, and various others. Modeling is based on the eating of manufactured foods containing Titanium dioxide [51].

Furthermore, recent findings of sodium consumption were correlated with higher BMI, WC, and body fat. Potassium eating was connected with lower BMI and smaller WC among US-born and participants with longer duration of US residence, that not agree with present work [52]. Future studies examining the longitudinal correlation among intakes of sodium, potassium, $\mathrm{Na}-\mathrm{K}$ ratio, $\mathrm{Ca}$, and variations in measures of obesity are needed. That will need further investigation to study the relation between $\mathrm{BMI}$ and heavy metals and minerals. Also, further investigation to prepare a reference range of body heavy metals and minerals to the Jazan population in $\mathrm{KSA}$ is needed to measure in both genders.

\section{Conclusion}

The conclusion is that there are increases in heavy metal minerals and metals in the human body in the present study. Furthermore, that not only depended on the BMI but also as a result of the increase in the effluent flow heavy metal from industrial units found in proximity to rivers, oceans, and seas have even ended to water bodies and seafood, fruits, and vegetable crops. That will need further investigation into variations of human body metals and minerals and measures its relation with obesity are required.

\section{Acknowledgement}

The authors want to thank all students who trusted us and were honest with us which made the research more accurate and effective. The corresponding author also appreciated Prof Ashraf Aly Moustafa Hassan for advice in the previous work related to BMI and choline esterase. Furthermore, the corresponding author thanks Madyha Hassan Mahmoud with Samia Farag Allah Salem in helping drawing some blood samples in the last work-related to BMI and choline esterase beside all people and doctors support that work. Please accept my gratitude and apology for forgetting.

\section{Conflict of Interest}

The authors declare that they have no conflict of interest.

\section{References}

[1]. Hamouda FA. (2016). The Association between Lifestyle, Anthropometric Measurements, and Obesity in University Students. J Pharm Pharmacol. 4:119-127.

[2]. Abdul R Al-A. (2011). Lipid Profile in Relation to Anthropometric Measurements among College Male Students in Riyadh, Saudi Arabia: A Cross-Sectional Study. Int J Biomed Sci. 7:112-119.

[3]. Eunim J, Whajin H, Yoona R, et al. (2016). A study on blood lipid profiles, aluminum and mercury levels in college students. Nutr Res Pract. 10:442-447.

[4]. Iwona R, Danuta K, Barbara D, et al. (2015). Relationship between the Concentrations of Heavy Metals and Bioelements in Aging Men with Metabolic Syndrome. Int J Environ Res Public Health. 12: 39443961.

[5]. Lin C, Hsu Y, Yen C, et al. (2018). Association between heavy metal levels and acute ischemic stroke. J Biomed Sci. 25: 49.

[6]. Syed MF. (2016). Correlation between serum trace elements and lipids in Patients with type 2 diabetes mellitus in jeddah, saudi arabia. Int J Sci Nat. 5:311317.

[7]. Soomro MH, Baiz NHG, Yazbeck C. et al. (2019). Exposure to heavy metals during pregnancy related to gestational diabetes mellitus in diabetes-free mothers. Sci Total Environ. 656: 870-876.

[8]. [Xin W, Bhramar M, Sung KP.(2019). Does Information on Blood Heavy Metals Improve Cardiovascular Mortality Prediction? Am Heart J. 8:e013571.

[9]. Hamouda FA, Ibrahim Abdu K, Ibraheem M $A$, et al. (2019). Study the Relation Between Acetylcholinesterase and Obesity in University Students. Int J Food Sci Nutr. 8:46-51.

[10]. Han FX, Patterson WD, Xia Y, et al. (2006). Rapid Determination of Mercury in Plant and Soil Samples Using Inductively Coupled Plasma Atomic Emission Spectroscopy, a Comparative Study. Water Air Soil Pollut. 170: 161.

[11]. Saleh AB, Ibraheem M. Attafi, ZH,et al. (2013). Effect of long-term human exposure to environmental heavy metals on the expression of detoxification and DNA repair genes. Environ Pollut. 181: 226-232.

[12]. Claire WY, Gortmaker SL, Taveras EM. (2011). Trends and racial/ethnic disparities in 365 severe obesity among US children and adolescents, 1976-2006. Int J Pediatr Obes. 366:12-20.

[13]. Ogden CL, Carroll MD, Kit BK, et al. (2012). Prevalence of obesity and trends in body 369 mass index among US children and adolescents, 19992010. JAMA. 307:483- 370490. 
[14]. Monisha J, Tenzin T, Naresh A, et al. (2014). Toxicity, mechanism and health effects of some heavy metals. Interdiscip Toxicol. 7: 60-72.

[15]. Szabo C, Ischiropoulus H, Radi R.(2007). Peroxynitrite: Biochemistry, pathophysiology and development of therapeutics. Nat Rev Drug Dicov. 6: 662-680.

[16]. Karrari P, Mehrpour O, Abdollahi M. (2012). A systemic review on status of lead pollution and toxicity in Iran; Guidance for preventive measures. DARU J Pharm Sci. 20:2.

[17]. Malekirad AA, Oryan S, Fani A, et al.(2010). Study on clinical and biochemical toxicity biomarkers in a zinclead mine workers. Toxicol Ind Health. 26:331-337. [

[18]. Alsaeed $A H$, Shaik AP, Faiyaz-ul-Haque $M$, et al. (2017). Evaluation of blood lead levels and their association with haematological and liver function test parameters in Saudi workers from Riyadh region, KSA. Biomed Res. 28: 1781-1785.

[19]. Neal AP, Guilarte TR.(2013). Mechanism of lead and manganese neurotoxicity. Toxic Res. 2: 99-114.

[20]. Papanikolaou NC, Hatzidaki EG, Belivanis S, et al. (2005). Lead toxicity update- A brief review. Med Sci Monitor.11:329.

[21]. Jones RL, Homa DM, Meyer PA, et al. (2009). Trends in blood lead levels and blood lead testing among USchildren aged 1 to 5 years, 1988-2004. Pediatrics.123:e376-385.

[22]. Dietrich KN, Ware JH, Salganik M, et al. (2004). Effect of chelation therapy on the neuropsychological and behavioral development of lead-exposed children after school entry. Pediatrics.114:19-26.

[23]. Ningjian W, Chi C, Xiaomin N, et al. (2015). Blood lead level and its association with body mass index and obesity in China - Results from SPECT-China study. Scient Reports. 5:18299.

[24]. Faulk C, Barks A, Liu K, et al. (2013). Early-life lead exposure results in dose- and sex-specific effects on weight and epigenetic gene regulation in weanling mice. Epigenomics. 5:487-500.

[25]. Leasure JL. (2008). Low-level human equivalent gestational lead exposure produces sex-specific motor and coordination abnormalities and late-onset obesity in year-old mice. Environ Health Perspect. 116:355-361.

[26]. Faulk C. (2014). Perinatal lead (Pb) exposure results in sex-specific effects on food intake, fat, weight, and insulin response across the murine life-course. PloS one. 9:e104273.

[27]. Zhang B. et al. (2015). Prenatal exposure to lead in relation to risk of preterm low birth weight: $A$ matched case-control study in China. Reprod. Toxicol. 57, 190195.

[28]. Matsuda M, Shimomura I. (2013). Increased oxidative stress in obesity: implications for metabolic syndrome, diabetes, hypertension, dyslipidemia, atherosclerosis, and cancer. Obes Res Clin Pract. 7:e330-341.
[29]. Sharma S, Raghuvanshi BP, Shukla S. (2014). Toxic effects of lead exposure in rats: involvement of oxidative stress, genotoxic effect, and the beneficial role of $\mathrm{N}$-acetylcysteine supplemented with selenium. J Environ Pathol Toxicol Oncol. 33: 19-32.

[30]. Ladabaum U, Mannalithara A, Myer PA, Singh et al. (2014). Obesity, abdominal obesity, physical activity, and caloric intake in US adults: 1988 to 2010. Am J Med. 127:717-727.

[31]. Scinicariello F, Buser MC, Mevissen M, et al.(2013). Blood lead level association with lower body weight in NHANES 1999-2006. Toxicol Appl Pharmacol. 273:516-523.

[32]. Rubio-Andrade M, Rosales-González M, HernándezOchoa M, et al. (2016). Relations between renal function, obesity andlow blood lead level in an environmentallyexposed population. Toxicology Letters. 259S:S73-S247.

[33]. Othman AM, Al-Othman ZA, El-Desoky GE, et al. (2013). Lead in drinking water and human blood in Riyadh City, Saudi Arabia. Arabian J Geosci. 6: 31033109.

[34]. Sarah A, Mansour S, Osman O. (2015). Possible Neuroprotective Role of Pomegranate Juice in Aluminum Chloride Induced Alzheimer's Like Disease in Mice. J Alzheimers Dis Parkinsonism. 5:188.

[35]. Alnasser S, Hussain SM, Kirdi TS, et al. (2018). Aluminum phosphide poisoning in Saudi Arabia over a nine-year period. Ann Saudi Med. 38:277-283.

[36]. Eunim J, Whajin H, Yoona R, et al. (2016). A study on blood lipid profiles, aluminum and mercury levels in college students. Nutrition Res Pract. 10:442-447.

[37]. Whitney SK, Timothy JW. (2016). Elevated blood lead and cadmium levels associated with chronic infections among non-smokers in a cross-sectional analysis of NHANES data. Environ Health. 15:1-13.

[38]. Bernier J, Brousseau P, Krzystyniak K, et al. (1 995). Immunotoxicity of heavy metals in relation to Great Lakes. Environ Health Perspect.103:23-34.

[39]. Amjad MS. (2017). Rice is a potential dietary source of not only arsenic but also other toxic elements like lead and chromium. Arabian J Chem. 10:S3434-S3443.

[40]. Iman A, Mai A.(2017). Heavy metals (lead, cadmium, methylmercury, arsenic) in commonly imported rice grains (Oryza sativa) sold in Saudi Arabia and their potential health risk. Int $\mathrm{J}$ Hygiene Environ Health. 220:1168-1178.

[41]. Tinkov AA, Filippini T, Ajsuvakova OP, et al. (2017). The role of cadmium in obesity and diabetes. Sci Total Environ. 1:741-755.

[42]. Qi W, Sheng W. (2018). Cadmium affects blood pressure and negatively interacts with obesity: Findings from NHANES 1999-2014. Science Environ. 643:270-276.

[43]. Othman MH. (2016). Risk Assessment of Heavy Metals in Fish in Saudi Arabia. Am J Environ Sci. 12:341-357. 
[44]. Abadi DRV, Dobaradaran S, Nabipour I, et al. (2015). Comparative investigation of heavy metal, trace and macro element contents in commercially valuable fish species harvested off from the Persian Gulf Environ Sci Pollut Res Int. 22:6670-6678.

[45]. Kazi TG, Afridi HI, Kazi N, et al. (2008). Copper, chromium, manganese, iron, nickel, and zinc levels in biological samples of diabetes mellitus patients. Biol Trace Elem Res.122:1-18.

[46]. Mostafa-Tehrani A, Ghorbani G, Zarre-Shahneh A, et al. (2006). Non-carcas components and wholesale cuts of Iranian fat-tailed lambs fed chromium nicotinate or chromium chloride. Small Ruminant Res. 63:12-19.

[47]. Zainy FMA, Bannani F, Alotaibi OA. (2018). Elemental Compositions of Some Eye Shadow Products Marketed in Saudi Arabia. J Cosmet Dermat Sci App. 8:236-243
[48]. Sharma AD. (2013). Low nickel diet in dermatology. Indian J Dermatol. 58:240.

[49]. Mohammad MH, Hussien AA, Mutaz AH. (2016). Health risk assessment of trace elements in drinking water from Najran City, southwestern Saudi Arabia. Arab J Geosci. 9: 464.

[50]. Alam F, Memon AS, Fatima SS. (2015). Increased Body Mass Index may lead to Hyperferritinemia Irrespective of Body Iron Stores. Pak J Med Sci. 31:1521-1526.

[51]. Esther LDP, Marcelo AM, Raquel FM. (2017). Cadmium, lead, tin, total mercury, and methylmercury in canned tuna commercialised in São Paulo, Brazil. Food Addit Contam Part B Surveill. 10:185-191.

[52]. Tali E, Yasmin M Linda VH, et al.(2018). Associations of sodium and potassium with obesity measures among diverse US Hispanic/Latino adults. Silver Spring. 26:442-450. 